Research Article

\title{
Research on assessment of suface water environment and sediment in seawater shallow area in Bac Lieu Province and proposing solutions for protection
}

\author{
Phu Huynh ${ }^{*}$, Han Huynh Thi Ngoc ${ }^{2}$ \\ ${ }^{1}$ Hochiminh City University of Technology (Hutech); h.phu@hutech.edu.vn \\ ${ }^{2}$ Hochiminh City University of Nature Resources \& Environment; \\ htnhan_ctn@hcmunre.edu.vn \\ *Correspondence: h.phu@hutech.edu.vn; Tel: +84-966687548
}

Received: 22 February 2021; Accepted: 20 April 2021; Published: 25 April 2021

\begin{abstract}
The quality of coastal water and sediment environment in Bac Lieu province tend to deteriorate due to waste (solid, liquid, gas) from the mainland into the river basins before being discharged into the sea. The paper presents the results of research on water quality in river basins dumping into the sea and coastal sediments. By methods of research, survey, observation, analysis of water quality, coastal sediment and calculation of WQI index, compared with QCVN 08-MT:2015/BTNMT, QCVN 43:2017/BTNMT (column sediments of salt water, brackish water). The results of physical and chemical parameters according to the dry season and the rainy season exceed the permitted threshold; pH: 6,69-9,20; TSS: 8-1,928 mg/l (exceeding 38.5 times). BOD 5 : 7-325 mg/l, COD: 13.8-602.6 mg/1, Ammonium $\left(\mathrm{NH}_{4}^{+}\right)$: 0.1-28.5 mg/l. WQI Nha Mat estuary: 37-73 and Ganh Hao seaport WQI: 52-68. Thus, the water environment in the continental river basins and coastal water quality shows signs of pollution from 2016 to 2020 . Sediments in the coastal area in 2018, there are 6/12 samples with high Arsenic concentration, in 20192020 there are $10 / 12$ areas with $\mathrm{Cd}, \mathrm{Pb}(0.57-0.83 \mathrm{mg} / \mathrm{l})$. This result will serve the planning, planning, management and control of water quality, coastal sediments and river basins to the coast of Bac Lieu Province in the direction of sustainable development.
\end{abstract}

Keyword: Bac lieu Province; The shallow seawater areas; Sediment; Water quality; WQI.

\section{Introduction}

In recent years (2016-2020), the environmental quatily of coast in Bac Lieu province tended to be worsened by the population growth and development of socio-economic activities. In which, the directly affecting the quality of the coastal environment in Bac Lieu province was wastewater from residential aseas, manufacturing facilities and introductrial zones, aquaculture, tourism activities, ect. flowing into the basin of rivers before to the sea.

Therefore, assessment of the effects of wastewater on the water quality of the rivers and canals from 2016 to 2020 is a necessary research. This study investigated and assessed the quality of water based on physical and chemical parameters, identified the main causes of pollution for the river basins that flow to the sea.

Domestic researches on marine pollution, proposing development models for some key areas, presented in detail the role of the sea and coastal in the industrialization and modernization of the country [1-4]. Some persistent organic pollutants in the coastal marine environment in the North of Vietnam" in the Monograph Series on the Sea, Vietnam Island, addressing problems in large coastal cities, this region has the potential to 
accumulate [5-6]. Persistent organic substances have the potential to adversely affect the environment, ecology and public health. One of the causes of marine environmental pollution is that wastewater from the IZs and EPZs pour directly into rivers, streams, canals, and canals and continue to flow into the sea.

Studies of marine environment in Asia-Pacific; The ASEAN-Canada project on marine pollution aims to define the criteria for marine resource protection and pollution management; The ASEAN-US project on coastal resource management aimed at developing an integrated coastal management plan; Project on the management of the marine and coastal environment in the East Sea by the Asian Development Bank (ADB5712-REG); Agreement on Environmental Protection of the East Sea and Gulf of Thailand dated March 28, 2001; International Law and Marine Environmental Protection, New York University, USA [7]. The book introduces a number of key contents such as the United Nations Environment Program (UNEP) and a joint statement "Stockholm Declaration" An introduction to the negotiation process and the basic contents of the United Nations Convention on the Law of the Sea 1982 (UNCLOS). UNCLOS is sometimes referred to as a "constitution of the oceans" because of its comprehensiveness and scope, in particular Part XII of UNCLOS deals with the protection and preservation of the Marine Environment with the obligation to general and state parties' specific obligations to prevent, reduce, and control pollution [6-13]. State policy on marine environment: 1972-2002, seas and coastal areas, Japan, Tokyo. Accordingly, the book mentions some basic contents such as: Increasing coastal and marine environmental degradation, the main threats to the oceans such as marine pollution, overexploitation, and environmental.

There have been many papers written on the issue of marine environmental pollution, marine economic activities in Vietnam as well as the impact of marine economic activities on the socio-economy. However, there is no specific topic mentioning the impact of marine environmental pollution on the socio-economic activities of Bac Lieu province today [1424]. Research on assessment of coastal pollution and coastal sediments in Bac Lieu Province will clarify the current environmental situation of coastal areas. coastal areas in Bac Lieu Province.

\section{Materials and methods}

\subsection{Description of study area}

Bac Lieu is a provancial city in the Mekong Delta region, covers an area of 266,900,08 hectares with coordinates from $9^{\circ} 0$ ' 0 " to $9^{\circ} 38^{\prime} 9^{\prime \prime}$ North latitude and from $105^{\circ} 14^{\prime} 15^{\prime \prime}$ to $105^{\circ} 51^{\prime} 54^{\prime \prime}$ East longitude. Bordering with Hau Giang and Kien Giang provinces in the North and Northwest; Bordering with Soc Trang province in the East and Northeast. Bordering with $\mathrm{Ca}$ Mau province in the West and Southwest; Bordering with the East Sea in the East and Southeast. Provincial administrative units: Bac Lieu city, Gia Lai town and 05 districts: Hong Dan, Phuoc Long, Vinh Loi, Dong Hai, Hoa Binh and a total of 64 comunes, wards, towns (Figure 1) [1-2].

\subsection{Methods}

\subsubsection{Methods of document collection, analysis and synthesis}

+ Collect references on natural conditions, socio-economic conditions, environmental and hydrological document of major rivers, main canals in Bac Lieu province;

+ Collect, statistic and update the characteristics of wastewater sources, characteristics of sources received from the field investigation, from related research projects and topics already in the region, from research institutions. rescue, production, business and service establishments; 
+ Collect documents on the theoretical basis to calculate the pollution of the different waste sources of the receiving source.

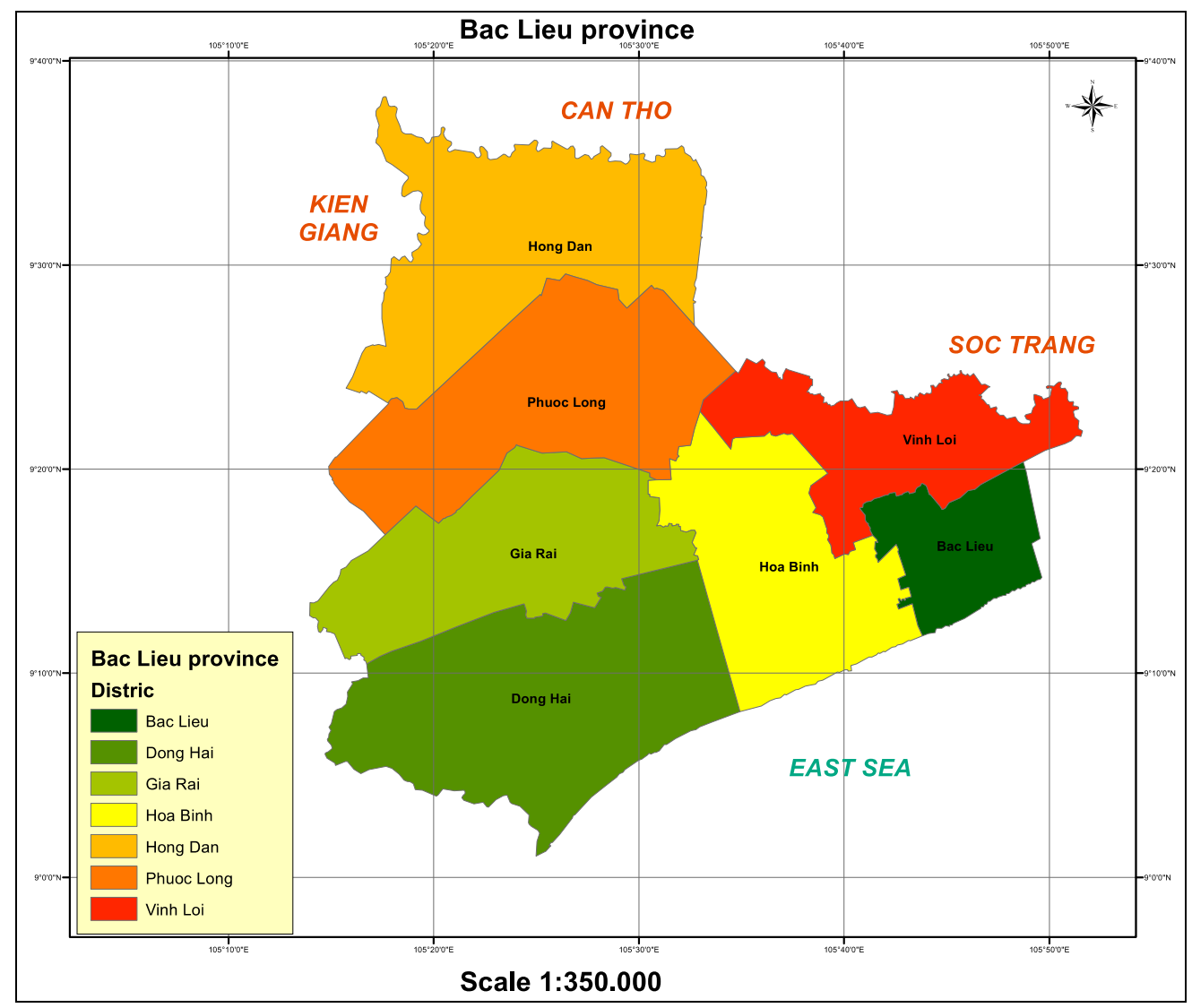

Figure 1. Administrative map of Bac Lieu province.

2.2.2. Methods of field survey, hydrological measurement, additional sampling and analysis

Field survey, hydrological measurement, sampling and analysis of wastewater, river water samples, sediment sampling to WQI calculation for water quality assessment. Compared with Vietnamese Standard QCVN 08-MT 2015/BTNMT.

2.2.3. Methods of analyzing, analyzing statistics and processing data

Synthesis, statistics, meteorological processing, hydrological and socio-economic data, dissecting the data of different waste sources have been investigated to calculate WQI for accurate assessment of surface water quality.

\subsubsection{Research data collection}

The data collection in this study are presented in Table 1 and Table 2.

Table 1. Sampling locations of coastal seawater in Bac Lieu Province.

\begin{tabular}{|c|c|c|c|}
\hline $\begin{array}{c}\text { Numerical } \\
\text { order }\end{array}$ & Symbol & Sampling locations & Note \\
\hline 1 & NBVB1 & $5 \mathrm{~km}$ from Nha Mat estuary & \\
\hline 2 & NBVB2 & $5 \mathrm{~km}$ from Nuoc Ngot canal (Vinh Trach Dong commune) & \\
\hline 3 & NBVB3 & $5 \mathrm{~km}$ from Cai Cung estuary & \\
\hline 4 & NBVB4 & $5 \mathrm{~km}$ from Ganh Hao estuary (Ganh Hao town) & \\
\hline 5 & NBVB5 & $5 \mathrm{~km}$ from the estuary of Huyen Ke canal (Dien Hai commune) & \\
\hline
\end{tabular}


Table 2. Sampling location for surface water environment monitoring in BacLieu province.

\begin{tabular}{|c|c|c|c|}
\hline $\begin{array}{c}\text { Numerical } \\
\text { order }\end{array}$ & Symbol & Sampling locations & Note \\
\hline 1 & NM1 & Cai Day canal, Chau Hung town, Vinh Loi district & \\
\hline 2 & NM2 & $\begin{array}{l}\text { Bac Lieu-Ca Mau canal, Hoa Binh town, Hoa Binh } \\
\text { district }\end{array}$ & $\begin{array}{l}\text { Bac Lieu-Ca } \\
\text { Mau canal (Hoa } \\
\text { Binh bridge) }\end{array}$ \\
\hline 3 & NM3 & 30/4 canal, Vinh Hau commune, Hoa Binhdistrict & \\
\hline 4 & NM4 & $\begin{array}{l}\text { Quan Lo Phung Hiep Canal, town } \\
\text { Phuoc Long, Phuoc Long district }\end{array}$ & \\
\hline 5 & NM5 & $\begin{array}{l}\text { Pho Sinh canal, Phuoc Long commune, Phuoc Long } \\
\text { district }\end{array}$ & \\
\hline 6 & NM6 & $\begin{array}{l}\text { Xom Lung canal, Lang Tron ward, } \\
\text { Gia Rai town }\end{array}$ & \\
\hline 7 & NM7 & $\begin{array}{l}\text { Outside Gia Rai sluice, Ward } 1 \text {, } \\
\text { Gia Rai town }\end{array}$ & \\
\hline 8 & NM8 & $\begin{array}{l}\text { Buu } 2 \text { canal, Kenh Tu, Dien Hai Commune, } \\
\text { Dong Hai district }\end{array}$ & \\
\hline 9 & NM9 & $\begin{array}{l}\text { Cau No.4 canal, Long Dien Dong Commune, Dong Hai } \\
\text { district }\end{array}$ & $\begin{array}{lr}\text { In } \quad 2017 \text { and } \\
2018, \\
\text { monitoring } \\
\text { conducted }\end{array}$ \\
\hline 10 & NM10 & $\begin{array}{l}\text { Tac Van canal, Lung Sinh hamlet, Dinh Thanh commune, } \\
\text { Dong Hai district }\end{array}$ & $\begin{array}{l}\text { No monitoring } \\
\text { was conducted in } \\
2017\end{array}$ \\
\hline 11 & NM11 & Cua Mat estuary, Bac Lieu City & \\
\hline 12 & NM12 & Hung Thanh sluice gate, Vinh Loi district & \\
\hline 13 & NM13 & Dau Bang sluice gate, Gia Rai town & \\
\hline 14 & NM14 & Chu Chi intersection, Phuoc Long district & \\
\hline 15 & NM15 & $\begin{array}{l}\text { Cai Cung sluice gate, Long Dien Dong commune, Dong } \\
\text { Hai }\end{array}$ & \\
\hline 16 & NM16 & Ganh Hao estuary, Dong Hai district & \\
\hline 17 & NM17 & Ninh Quoi crossroads, Hong Dan district & \\
\hline 18 & NM18 & Vinh Loc-Ba Dinh, Hong Dan district & \\
\hline
\end{tabular}

\section{Results and Discussion}

3.1. Evolution of water quality according to physical and chemical criteria from river channels to the sea in Bac Lieu province

Surface water quality have been based on physical and chemical indicators, such as $\mathrm{pH}$, $\mathrm{DO}, \mathrm{BOD}_{5}, \mathrm{COD}$, TSS (Total suspended solids), $\mathrm{N}-\mathrm{NH}_{4}, \mathrm{P}-\mathrm{PO}_{4}$, Turbidity, Coliforms. The $\mathrm{pH}$ of period from 2016 to 2020 ranged from 6.69 to 9.20 ; the $\mathrm{pH}$ of the Cau No. 4 canal (NM9) was higher than the maximum allowed value in 2019 and $\mathrm{pH}$ was in the allowable value range (B1) at the remaining locations. 




Figure 2. The variability charts of the water quality has been based on the physical and chemical indicator. 


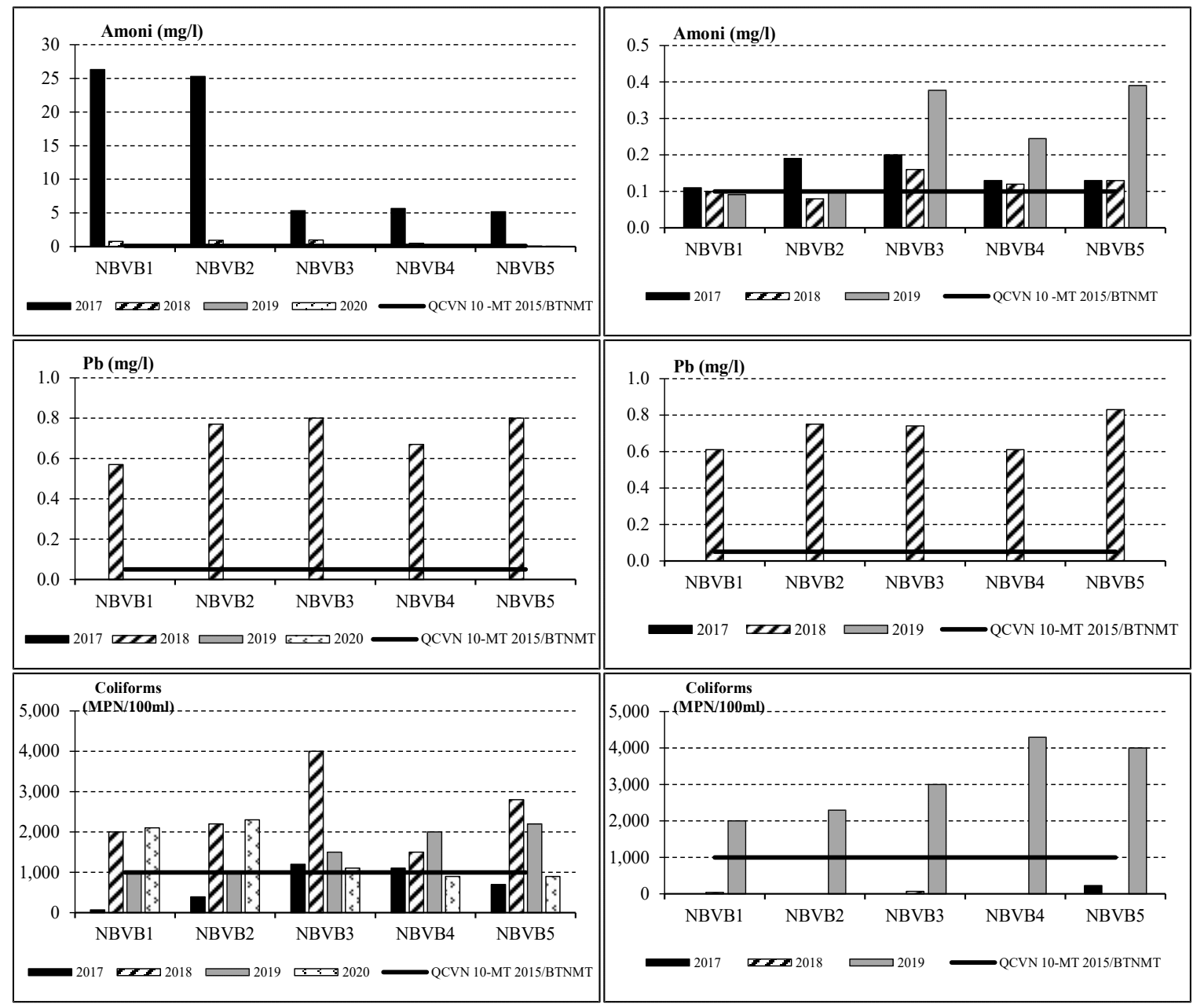

Figure 2. The variability charts of the water quality has been based on the physical and chemical indicator (continute).

In 2016, the $\mathrm{BOD}_{5}$ was lower than the allowable value and this indicator has increased higher and higher than the maximum allowed value over the 2017-2020 period. In the rainy season, $\mathrm{BOD}_{5}$ parameter fluctuated from 8 to $410 \mathrm{mg} / \mathrm{l}$. The highest parameter of $\mathrm{BOD}_{5}$ was at 30/4 canal, Hoa Binh district (NM3) in 2020 and the lowest value was at Cai Day canal, Chau Hung town, Vinh Loi district (NM1) in 2016. In the dry season, the BOD 5 fluctuated from 7 to $325 \mathrm{mg} / \mathrm{l}$. The highest value of $\mathrm{BOD}_{5}$ was at Cai Cung sluice gate, Dong Hai district (NM15) in 2017 and the lowest value was at 30/4 canal (NM3) in 2016. In 2017, this indicator has increased dramatically at the locations that were observed near the estuary such as Buu 2 canal (NM8), Nha Mat estuary (NM11), and Cai Cung sluice gate (NM15).

TSS indicator of surface water had a significant difference between the two seasons of the year during the period from 2016 to 2020. In the rainy season, TSS was higher than the maximum allowable limit, made up from 8 to $1,928 \mathrm{mg} / 1$. In which, TSS was many times larger than the the allowed limit at 30/4 canal (NM3), Buu 2 (NM8) canal, Cai Cung sluice gate (NM15) and Ganh Hao gate (NM16). The highest parameter of TSS was at Buu 2 canal, Dong Hai district $(1,928 \mathrm{mg} / \mathrm{l}$, exceeded 38.5 times) in 2019. In the dry season, TSS was nearly equality or exceeded the maximum allowed value $(21.43-1,011 \mathrm{mg} / \mathrm{l})$. The highest parameter of TSS was at Buu 2 canal (NM8), which accounted for $986 \mathrm{mg} / 1$ (exceeded 32.8 times) in 2019.

In 2016, COD was lower than the maximum permitted standard. COD increased highly from 2017 to 2020 , stood at $13.8-602.6 \mathrm{mg} / \mathrm{l}$ in dry season. The COD was highest at 30/4 
canal, Hoa Binh district (NM3) in 2020 and lowest at Cai Day canal, Chau Hung town, Vinh Loi district (NM1) in 2016. In the rainy season, COD ranged 11-487 mg/l, COD was highest at Buu 2 canal (NM8) in 2017 and lowest at 30/4 canal (NM3) in 2016. In 2017, coastal monitoring locations: Buu 2 canal, Nha Mat, Cong Cai estuary, COD climed dramatically. In rainy season, COD decreased compared to dry season. DO indicator in surface water ranged from 4.0 to $7.9 \mathrm{mg} / \mathrm{l}$ in the 2016-2020 period. The monitoring positions reached the limit QCVN 08-MT:2015/BTNMT, level B1. In the rainy season, DO at the locations of Cai Day (NM1), Bac Lieu-Ca Mau (NM2), 30/4 canal (NM3), Pho Sinh (NM5) and Xong Lung canal (NM6) was high, ranging from 7.01 to $7.92 \mathrm{mg} / \mathrm{l}$ in 2017.

Ammonium met the permitted standards in 2016. Ammonium changed significantly over the 2017-2020 period. In the dry season, Ammonium fluctuated from 0,1 to 28,5 mg/l. In general, Ammonium at monitoring positions met the permitted standards in 2016, 2019 and 2020. In the rainy season, Ammonium fluctuated greatly but lower than the dry season, ranging from $0.06-2.46 \mathrm{mg} / \mathrm{l}$. In 2016, Nitrite indicator met the permitted standards, but this figure changed significant in the 2017-2020 period. In 2019, the parameter of Nitrite increased very high, many times higher than the permitted value. In the dry season, there were 16/18 monitoring positions where the Nitrite indicator was higher than the maximum allowable value. In the rainy season, the parameter of Nitrite rised higher than in the dry season, ranging from 0.002 to $1.123 \mathrm{mg} / \mathrm{l}$. 30/4 canal (NM3), $1.123 \mathrm{mg} / \mathrm{l}$, Cai Day Canal (NM1), $0.683 \mathrm{mg} / \mathrm{l}$ and Bua 2 canal (NM8), $0.583 \mathrm{mg} / \mathrm{l}$. In the rainy season, Nitrite fluctuated from 0.002 to $0.558 \mathrm{mg} / \mathrm{l}$, all monitoring positions had nitrite parameter higher than the permitted maximum level. In which, the location with the highest Nitrite was Hung Thanh (NM12) and the location with the lowest Nitrite was Cai Day canal (NM1).

In the dry season, the phosphate was higher than the maximum allowable value in 2016 and 2017. Especially, Photphate parameter at 4 locations, Nha Mat (NM11), Cai Cung sluice gate (NM15), Ganh Hao (NM16), Ninh Quoi intersection (NM17) and Vinh Loc-Ba Dinh (NM18) was many times higher than the permitted standard in 2017. Phosphate tended to decrease much compared to previous years and its value was lower than the maximum permitted limit. The phosphate in the rainy season was much lower than one in the dry season $(0.0-0.97 \mathrm{mg} / \mathrm{l})$. In 2017, the phosphate was the highest in all years, such as Cai Day canal (NM1), Bac Lieu canal-Ca Mau (NM2), Cua Ganh Hao (NM16).

Chloride in surface water was higher than the maximum value, column B1 in 2016, 2018, 2019 and 2020. In the dry season, chloride fluctuated signifincantly, 2.2-22.759 $\mathrm{mg} / \mathrm{l}$. the location had high chloride, Dau Bang (NM13), made up $22.759 \mathrm{mg} / \mathrm{l}$ in 2020, chloride parameter of Xom Lung canal (NM6) was $21.128 \mathrm{mg} / 1$ in 2020 . In the rainy season, chloride was about 42.00-19.143 mg/l. Some monitoring locations had high chloride, such as chloride parameter of Nha Mat (NM11) was $19.143 \mathrm{mg} / 1$ in 2018 and Tac Van Canal (NM10) had a chloride parameter o $17.069 \mathrm{mg} / \mathrm{l}$ in 2016 . The indicator of total iron in surface water ranged from 0.03 to $2.97 \mathrm{mg} / 1$ in the $2016-2019$ period. In the dry season, total iron ranged from 0.03 to $2.37 \mathrm{mg} / \mathrm{l}$. There were $5 / 18$ monitoring locations with total iron higher than allowed maximum, 30/4 canal (NM3) in 2019, Gia Rai sluice (NM7 ) in 2016, Buu 2 canal (NM8) in 2016, Cau No.4 canal (NM9) in 2020 and Tac Van canal (NM10) in 2020, the remaining locations were lower than the permitted limit. In the rainy season, the parameter of total iron was from 0,1 to $4,84 \mathrm{mg} / 1$. There were $9 / 18$ monitoring positions with the parameter of total iron was higher than the maximum allowed value. The location with the highest parameter of total iron was Buu 2 canal (NM8) in 2020, the location with the lowest total iron value was Dau Bang (NM13).

The indicator of total Coliforms in surface water was lower than the maximum allowed limit in the 2016-2020 period. In the dry season, parameter of total Coliforms was 759.500 MPN/100 ml, there were 02/18 monitoring positions in 2020, which were at Cai Day canal (NM1) and Quan Lo Phung Hiep canal (NM4) with parameter of total Coliforms was 
higher than the allowed limit. In the rainy season, the parameter of total Coliforms was 230-10.200 MPN/100 ml, with 6/18 monitoring locations were Cau No.4 canal (NM9) in 2016; Cai Day canal (NM1), Quan 3 canal and Figure 4. Phung Hiep (NM4), Cua Nha Mat (NM11), Chu Chi intersection (NM14) and Ninh Quoi crossroad (NM17), the parameter of total Coliforms was higher than the maximum allowed standard in 2019.

\subsection{The variation in water quality of rivers and canals flowing into the sea according to} WQI index

Calculating WQI index (2016-2020) was based on the results of physical and chemical parameters ( $\mathrm{pH}$, Coliforms, $\left.\mathrm{NO}^{3-}, \mathrm{NO}^{2-}, \mathrm{BOD}_{5}, \mathrm{COD}, \mathrm{NH}^{4+}, \mathrm{PO}_{4}{ }^{3-}, \mathrm{DO}\right)$ of water quality at monitoring locations (Table 2). Calculation results are shown in Figures 3 and 4.

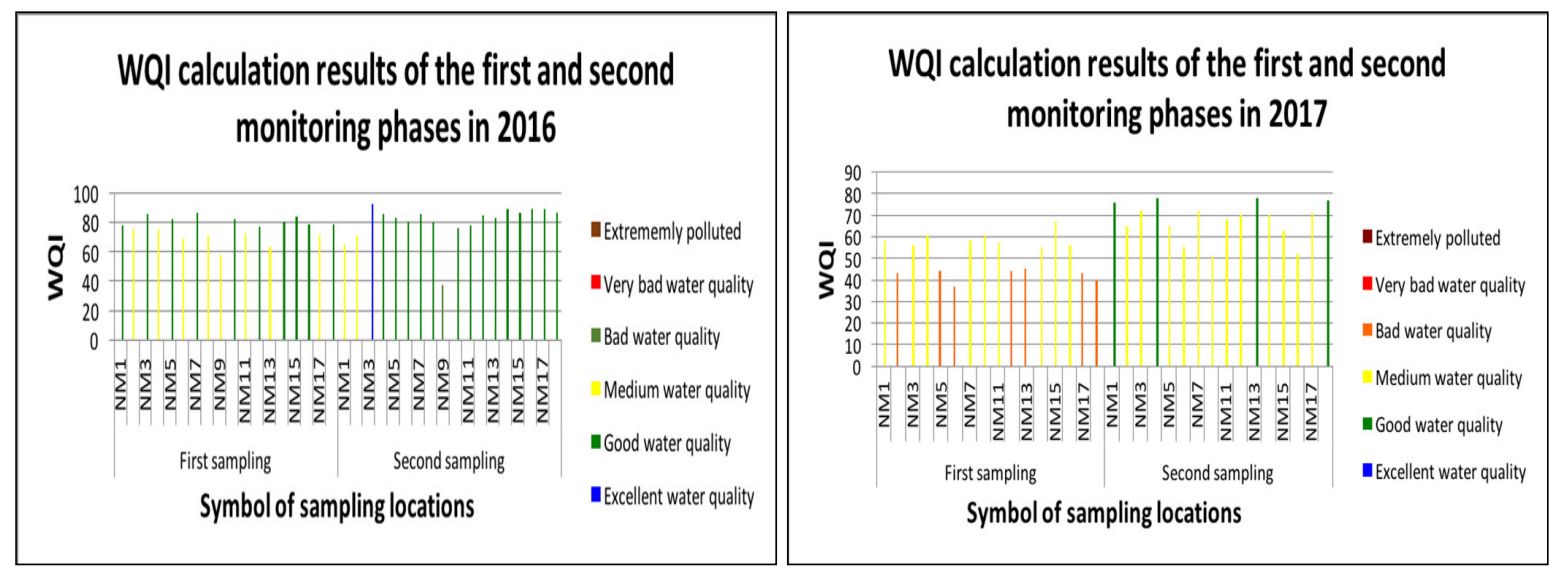

Figure 3. WQI indicators of the first observation in 2016 and 2017.
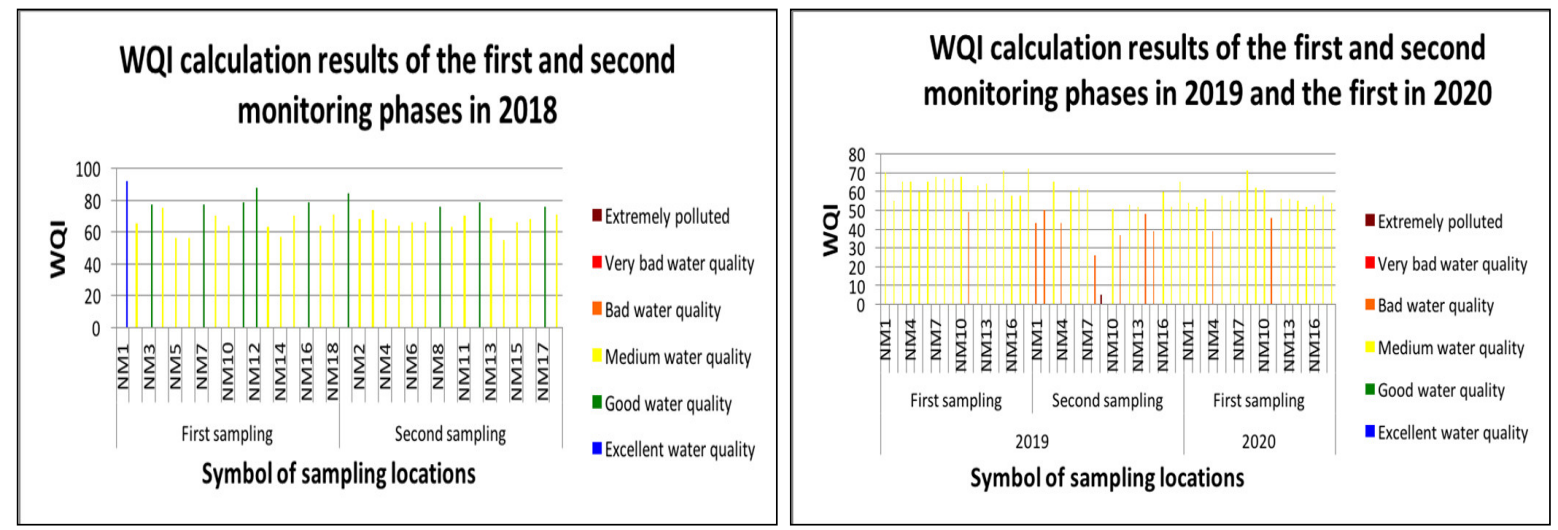

Figure 4. WQI indicators of observation in rainy and dry seasons in 2018, 2019 and 2020.

\subsection{The variation of the quality in coastal sediments in Bac Lieu province}

The variation of pollution parameters in coastal sediments of Bac Lieu province during the period from 2016 to 2020, the results of two monitoring periods, corresponding to dry and rainy seasons, compared with QCVN 43:2017/BTNMT-National technical regulation on sediment quality (sediment column of salt water, brackish water).

Heavy metals in marine sediments, such as Arsenic, Cadmium, $\mathrm{Cu}$, and Chromium at all positions were lower than the permitted limit (2016-2020). The value of analyzed parameters had a significant variation between years (Figures $4 \mathrm{a}-4 \mathrm{~d}$ ) but there was no pollution manifest.

In 2018 , there were $6 / 12$ soil samples with arsenic $>8 \mathrm{mg} / \mathrm{l}$ in the coastal area of Chau Thoi commune. Also in those locations, it was $\mathrm{Zn}>10 \mathrm{mg} / \mathrm{l}$ in 2019. In 2020, there were $10 / 12$ soil samples with $\mathrm{Cd}>9 \mathrm{mg} / \mathrm{l}$, higher than the standard. 

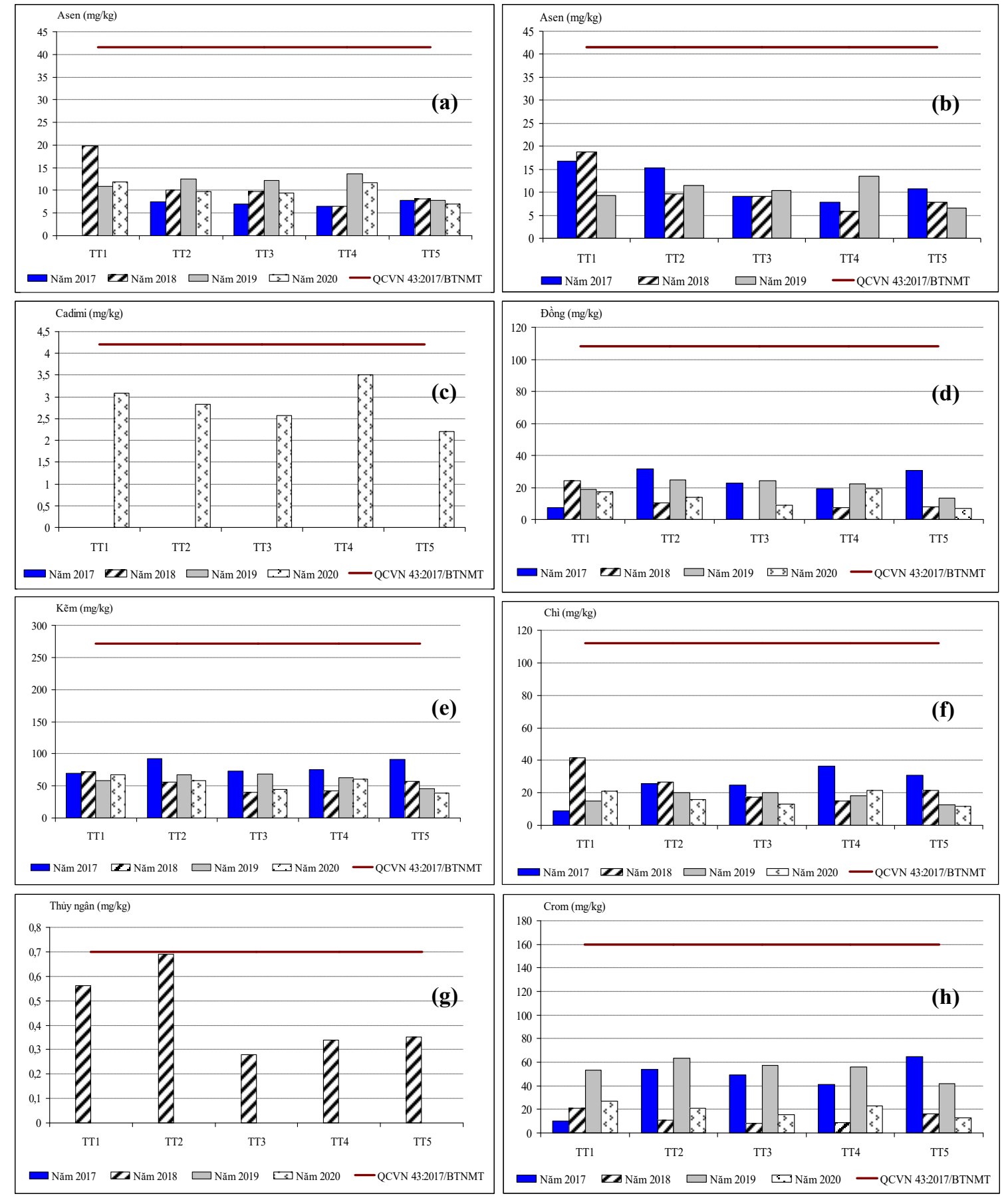

Figure 5. The charts show the variation of heavy metals in sediments: (a) The variation of As in the dry season; b) The variation of the As in the rainy season; c) The variation of the Cd in the dry season; d) The variation of the $\mathrm{Cu}$ in the dry season; e) The variation of the $\mathrm{Zn}$ in the dry season; f) The variation of the $\mathrm{Pb}$ in the dry season; g) The variation of the $\mathrm{Hg}$ in the dry season; $\mathrm{h}$ ) The variation of the $\mathrm{Cr}$ in the dry season.

\subsection{Proposing solutions for protection}

Perfecting waste source management mechanisms and policies, economic tools are used to influence costs and benefits in the operation of economic organizations to create impacts on the behavior of economic organizations that was beneficial for the environment. Managing different sources of waste accords to directive No. 25/CT-TTg dated 31/8/2016 of the Prime Minister of Vietnam on a number of urgent tasks and solutions to environmental protection, assigning the provincial People's Committee to force factories 
with large-scale of wastewater discharge to install monitoring equipment to control and monitor their discharge in accordance with the provisions of Vietnamese law and report directly to the Department of Natural Resources and Environment to perform waste source management. Conducting propaganda to raise awareness of the community and businesses was through the media or practical operation models. Building a network of automatic water environmental monitoring stations, enhancing environmental supervision-monitoring at factories in the area and setting up a mobile monitoring-monitoring unit are very necessary.

\section{Conclusion}

The article analyzed and evaluated the water quality through physical and chemical parameters, the results of monitoring the quality of surface water environment during the period from 2016 to 2020 showed that the physical and chemical parameters, such as TSS, $\mathrm{BOD}_{5}, \mathrm{COD}$, Ammonium, Nitrite, Phosphate, Total Iron, Chloride, and Colifoms exceeded the permitted standards (QCVN 08-MT:2015/BTNMT-level B1). In which the parameters: TSS, BOD5, COD, Ammonium, Phosphate, Chloride were many times higher than the standard. The WQI indicator fluctuates significantly in the 2016-2020 period, WQI tended to decrease gradually, showing the green color from 2016 to 2020, most of the sampling indicators was yellow color WQI $<70$, showing slightly polluted water to polluted; variation in surface water quality in Bac Lieu province were changing towards more and more pollution in the 2016-2020 period. The average water quality indicator on 18 monitoring locations in the first observation in 2016 on the VN-WQI was 76 (good level), by the first observation in 2020, the average water quality indicator on the VN-WQI was only 55 (average). The parameters of coastal sediments were below the allowed threshold according to QCVN 43:2017/BTNMT- saline and brackish sedimentary column. Proposing solutions to prevent environmental pollution and towards the sustainable development of water environment in coastal areas of Bac Lieu province.

Acknowledgments: The article is completed from the results of the implementation of the study "Assessment of environmental pollution impacts in coastal areas originating from socio-economic activities in Bac Lieu province and proposing mitigation measures". (2019-2020). Phu My Institute for Environmental Technology Promotion and Water Resources.

Authors contribution: Contructing research idea: P.H.; H.H.T.N.; Select research methods: P.H; H.HTN; Survey sampling and analysis: P.H; H.HTN; Data processing: P.H.; H.H.T.N.; Writing original draft preparation: P.H.; H.H.T.N.; Writing-review and editing: P.H.; H.H.T.N.

Conflicts of interest: The authors declare no conflict of interest.

\section{References}

1. Guidelines for the formulation of integrated coastal management strategy for coastal provinces of Vietnam. Department of Environmental Protection. Ministry of Natural Resources and Environment, 2007.

2. Assessment of environmental pollution impacts in coastal areas originating from socio-economic activities in Bac Lieu province and proposing mitigation measures. Phu My Institute for Environmental Technology Promotion and Water Resources, 2019.

3. Report on environmental status of Bac Lieu province for the period 2016-2020, Center for environmental monitoring, 2020.

4. Abdullah, A.; Hutomo, M. Marintinge Protected Area-matter and Development, Jakarta, Indonesia, 1995. 
5. Abrahamsson, J.B. Marine Environment and shipping, The IO Foundation, 1977.

6. Assessment of environmental pollution impacts in coastal areas originating from socio-economic activities in Bac Lieu province and proposing mitigation measures, 2020.

7. Schiffman, H.S. International law and the protection of the Marine environment. International Law And Institutions, Encyclopedia of Life Support Systems (EOLSS), 2003.

8. Bac Lieu Statistical Office, Bac Lieu Statistical Year book. 2017, 2018, 2019.

9. Biliana, C.S.; Robert, W.K. Integrated management of coastal and marine, University of Delaware, Newark, USA, 1998.

10. Ca, V.T. Marine environment concept and issues of marine environment. Publisher of Research on Marine and Island Management, Vietnam Administration of Sea and Islands, 2009.

11. Central Science and Education Department, Ministry of Science and Technology and Environment, Towards consolidating the system of state management agencies on environmental protection in Vietnam, 2001.

12. Chanyut, S.; Edward L. W. Results of State management over mangrove community based in Southern Thailand, Bangkok. Ecol. Soc. 2008, 13, 2.

13. Charles, N.E. Toward a common framework for integrated coastal zone management, the National Oceanic Bureau (NOS), Oceanic Administration and the U.S. National Atmospheric Administration (NOAA), Proceedings of the workshop, 2002

14. Decree No. 80/2014 / ND-CP dated August 6, 2014, Decree on drainage and wastewater treatment, 2014.

15. Circular No. 02/2009/TT-BTNMT dated 19/03/2009 regulating the assessment of the sources to rest wastewater. Ministry of Natural Resources and Environment, 2017.

16. Decision No. 341/QD-BTNMT dated 23/03/2012 promulgating the list of rivers within the province, Ministry of Natural Resources and Environment, 2012.

17. National overall environmental status report in 2006-2010. Ministry of Natural Resources and Environment, 2010.

18. QCVN 08-MT:2015/BTNMT, National technical regulation on surface water quality. Ministry of Natural Resources and Environment, 2015.

19. QCVN11-MT:2015/BTNMT, National technical regulation on industrial wastewater from seafood processing industry. Ministry of Natural Resources and Environment, 2015.

20. Decision 1327/2002 / QD-BYT dated 18/04/2002 promulgating industry standard regional polyclinics design standards. Ministry of Health, 2002.

21. Phu, H. Method of calculation \& application of WQI index to assess the status water quality and proposal of management Luy river Binh thuan province. $V N J$. Hydrometeorol. 2019, 02, 9-15.

22. Huynh, P. Irrigation construction solution for rising Litopenaeus Vannamei in Mekong delta. The international conference on science, technology and society studies (STS), HUTECH 2020, 92-97. ISBN 978-604-67-1574-0.

23. Phu, H. Solution for water circulation in raising Litopenaeus vannamei (Whiteleg shrimp) in Bac Lieu province. The international conference on science, technology and society studies (STS), HUTECH 2020, 97-103. ISBN 978-604-67-1574-0.

24. Triet, L.M. Building a number of scientific bases for the unified and integrated management of water environment in Dong Nai river basin. Institute of Environment and Natural Resources, 2005. 